University of Denver

Digital Commons @ DU

Educational Leadership and Policy Studies:

Faculty Scholarship

Educational Leadership and Policy Studies

$10-11-2021$

Approved to Fail: A Case Study of Leadership at Three New High Schools

Sarah Melvoin Bridich

Follow this and additional works at: https://digitalcommons.du.edu/elps_fac

Part of the Educational Administration and Supervision Commons, and the Educational Leadership Commons

(c) (1) (8)

This work is licensed under a Creative Commons Attribution-NonCommercial 4.0 International License 


\section{Approved to Fail: A Case Study of Leadership at Three New High Schools}

\section{Publication Statement}

This is an Accepted Manuscript of:

Bridich, S.M. (2021). Approved to fail: A case study of leadership at three new high schools. Journal of Educational Administration, 59(6), 794-810. https://doi.org/10.1108/JEA-03-2021-0058 


\title{
Approved to Fail: \\ A Case Study of Leadership at Three New High Schools
}

\begin{abstract}
Purpose: This paper explores how leaders of new public high schools - one charter and two innovation schools - navigated the journey from school-in-theory to school-in-practice during the school's first three years. School leaders at charter and innovation schools have increased freedom over curriculum, budget, scheduling, and personnel when compared to leaders in traditional public schools.

Methodology: Using case study research, this qualitative, multisite study of school leaders at three schools in an urban district in Colorado examined the realities leaders experienced during the first three years of their schools. School leaders participated in semi-structured interviews, which were coded and analyzed for data individual to each school and across the three schools. Initial school design plans and district accountability data were also reviewed.

Results: The study identified two distinct challenges for leaders of these new schools: (1) opening a new school contributes to burnout among school leaders; and (2) school leaders face systemic, district-level barriers that impede implementation of a school's founding mission and vision.

Research limitations: A qualitative study of three standalone charter and innovation schools in one urban school district limits generalizability.

Originality/value: The lived experience of school leaders at new, standalone charter and innovation schools is largely neglected in empirical studies. This research illuminates key struggles school leaders experience as they seek to establish new schools with fidelity to districtapproved school plans.
\end{abstract}

Keywords: Leadership, Charter Schools, Innovation Schools, School Reform, Educational Innovation, Burnout

Paper Type: Research paper

\section{Introduction}

As the school choice movement moves into its fourth decade in the United States (U.S.), debates still rage around its effectiveness for improving student learning (Finn et al., 2017). Yet the number of students enrolled in charter schools in the U.S. increases annually (National Center for Education Statistics, 2021), with non-profit Charter Management Organizations (CMOs) and both non-profit and for-profit Educational Management Organizations (EMOs) seeing significant enrollment expansion in recent years (Miron et al., 2021). In line with this trend, the State of Colorado continues to open new charter and innovation schools annually. Yet, a majority of these schools are standalone schools - not members of either a CMO or an EMO. 


\section{Brief Overview of Charter and Innovation Schools in Colorado}

An early adopter of school choice, Colorado's legislature approved the creation of charter schools in 1993 as a method to explore new approaches to teaching and learning. Districts were asked to authorize new schools if they deemed the new schools' plans worthy (Windler, 1996). Holding fast to the adage of "autonomy in exchange for accountability" (Miron et al, 2021, p. 24), Colorado later expanded its choice offerings to include innovation schools. The 2008 Innovation Schools Act “encourage[d] innovation" by providing additional school leaders with "greater control over levels of staffing, personnel selection and evaluation, scheduling, and educational programming with the goal of achieving improved student achievement" (p. 2). In the 2019-2020 school year, Colorado was home to 260 charter schools, of which over $50 \%$ were standalone (i.e., no CMO or EMO affiliation) (Colorado Department of Education, 2020), and 106 innovation schools, of which over $60 \%$ were standalone (Kottenstette and Paga, 2020). In Colorado, the Department of Education considers all charter schools "public," even when connected to an EMO (Colorado Department of Education, 2020; Miron et al, 2021).

Both charter and innovation schools have autonomy over curriculum, budget, scheduling, and personnel in Colorado. Charter schools receive automatic waivers around local board policies and teacher employment and do not receive district support services like human resources and transportation (Colorado Department of Education, 2020). Leaders at innovation schools may apply for waivers from district mandates, but still have access to district support services. Like charter schools, innovation schools have a district-approved plan that includes its mission and vision and methods of transforming this into action. The state of Colorado considers charter schools to be only "partially autonomous" as these schools have a charter yet are "remaining within the school district" (Colorado Department of Education, 2021b). 
Although charter and innovation schools differ from traditional public schools (TPSs) in many ways, the licensing requirements for school leaders are largely the same (Colorado Educator Licensing Act of 1991). School building leaders in all public schools - including charter and innovation schools - need a principal license and are eligible for either an initial license or a "principal authorization," an alternative license that enables a leader to take on the principal role while still completing formal schooling (Colorado Department of Education, 2021a). Charter schools are eligible to apply for waivers from such licensure from the State Board of Education, as part of their charter application.

The role of the school district is complex for charter and innovation schools, with the district acting as both authorizer and accountability enforcer. Additionally, different branches of the district are responsible for these distinct pieces: the school board approves or denies a charter application or an innovation plan; the district staff is responsible for school oversight and ensuring it is in compliance with district and state standards. Dual district roles can lead to conflicting objectives. For example, the district's elected school board may authorize a charter or innovation school, but the district's central office staff is responsible for providing resources, support, and oversight of the new school. If these two entities are aligned, the split responsibilities can work in tandem: the board approves the new charter school and the district staff works with school leaders to bring the vision to life, offering support as needed. However, if the district groups are misaligned, this dichotomy can prove disastrous: the board approves a new charter or innovation school while unaware of or despite enrollment constraints, available facilities, or the district staffs' perceptions of school choice, including their willingness - or not to "relinquish control to schools" (Honig and Rainey, 2014, pp. 487-488). The potential for misalignment is real in Colorado, for the incentives differ between the board and district staff: 
the board is beholden to Colorado's Charter School Act, including a potential appeal process that goes up to the State Board of Education should the initial charter application be denied (Colorado Revised Statutes, 2016), and district staff are not.

\section{Seeking to understand lived realities for school leaders at new public high schools}

When individuals propose charter and innovation school plans to their districts for approval, the extensive application includes mission and vision statements. If approved, it is incumbent upon the school leader to bring the mission and vision to life. Historically, the school leader is responsible for maintaining a positive school culture (Spillane et al., 2001; Yan, 2020) and ensuring student success (Bauer and Silver, 2018). In a new school, the school leader is responsible for creating both the school culture and conditions for student success, (Campbell and Gross, 2008) as articulated in their district-approved charter and innovation plans. Thus, school leaders play an outsized role in their school's success.

The size of standalone charter and innovation schools has generally discouraged empirical research (Bulkley and Fisler, 2003). Yet, as a majority of Colorado's charter and innovation schools are standalone, understanding the realities of opening such schools is vital. To add to the limited research on standalone charter and innovation school leaders, particularly in the inaugural years, the present study answers the following research question: How do new school leaders navigate the first three years, moving from a school in theory to a school in practice?

\section{Review of the literature}

As school choice has been gaining momentum in the U.S., it has also been growing internationally (Finkelstein and Grubb, 2000; Altichter, 2010; Dong and Li, 2019). In some 
nations, though, "school choice" refers to choices between public and private, or governmentfunded and non-government funded schools, rather than among types of public schools as in the U.S. (Cahill and Gray, 2010). As many nations wrestle with how to provide a quality education for their students, school choice remains an active reform. Yet, wherever school choice is happening, and however it is defined, there is an increased sense of competition among schools and for students (Jabbar, 2015; Jabbar, 2016; Potterton, 2019; Miron et al, 2021), and increased parental anxiety around the school decisions (Cahill and Gray, 2010; Dong and Li, 2019).

Competition among schools and for students is becoming increasingly pronounced in the U.S., particularly with the rise of CMOs and EMOs. Originally, charter schools were to be "locally run, innovative, autonomous, and highly accountable" (Miron et al, 2021, p. 6) and school choice more generally was to pressure schools "to improve to attract and retain students" (Jabbar, 2016, p. 399). EMOs have experienced "tremendous growth" in the number of public schools they control (Miron et al, 2021, p. 4)(for additional information about EMOs, please see Miron et al., 2021). A recent study of school leaders in an Arizona school district and surrounding area revealed that leaders in all schools - TPSs and EMO charter schools alike - feel intense competition for students, leading to increased leadership turnover among other things (Potterton, 2019). Similarly, an examination of the district-wide choice model in post-Katrina New Orleans revealed that school leaders gave considerable energy to creating a competitive advantage for their schools, such as investing in marketing practices or developing a niche academic program, to boost student enrollment (Jabbar, 2015).

Increased competition makes the work of leading a school even more challenging. School leaders are widely considered a highly influential factor on student learning (Waters et al., 2003; Leithwood et al., 2004; Chetty et al., 2011; Yan, 2020). However, the job has become 
progressively complex (Bauer and Silver, 2018; Gawlik, 2019; Thessin and Louis, 2019) with responsibilities ranging from discipline to visibility, culture to communications (Waters et al., 2003). In addition, school leaders are expected to serve as instructional leaders (Levine, 2005; Allen and Gawlik, 2009; Thessin and Louis, 2019), "intensively and continuously" working with teachers to improve their craft (Honig, 2012, p. 736). These already high expectations for school leadership (Rothstein, 2001) are further intensified in charter and innovation schools with the addition of operational demands and time-intensive regulatory paperwork (Campbell and Gross, 2008; Ni et al., 2015; Gawlik, 2019; Kingsbury et al., 2020). In fact, leading a charter school has been compared to leading an independent school (Finn et al., 2017) and serving as district superintendent (Allen and Gawlik, 2009).

As the complexity of being a school leader has increased, so too have concerns around leadership sustainability (Ni et al., 2015; Finn et al., 2017; Bauer and Silver, 2018; Gawlik, 2019; Yan, 2020). Most individuals who become school leaders come from within school ranks (Elmore, 2000; Bierly and Shy, 2013). Although some formal mentorships exist within principalpreparation programs (Cleaver, 2010; Bierly and Shy, 2013; Levin and Bradley, 2019; Connery and Frick, 2021), most leadership preparation still happens in the university classroom, where curriculum varies widely across institutions (Levine, 2005). In addition to uneven leadership preparation at the university level, Levin and Bradley (2013) locate four determinants of leader attrition within the job itself: poor working conditions, insufficient salaries, lack of decisionmaking authority, and high-stakes accountability policies (p. 3). The pressure on leaders is real, as Thessin and Louis (2019) noted: "the conflating of school-level appraisals with school leader appraisals is common: the assumption that if a school is doing better, the school leader must be doing something right" (p. 437). Conversely, if a school is doing poorly, the leader is 
accountable. Another challenge around leadership sustainability is isolation (Zellner et al, 2002). Feeling a connection to coworkers is a "significant predictor of job satisfaction;" conversely, feeling alone at work leads to dissatisfaction (Bauer and Silver, 2018, p. 318). Alarmingly, Liou and Daly (2018) found that school leaders' sense of isolation increases over time in the job, rather than diminishing.

Over the past two decades, principal burnout and turnover soared to 25\% (School Leaders Network, 2014). Besides the very real financial costs of turnover (School Leaders Network, 2014), students experience learning costs during leadership transitions. Leadership transitions can cause institutional memory loss and negatively impact on school culture, climate, and goals (Ni et al., 2015). The impact is even greater at new schools, where the school leader is responsible for developing school culture (Campbell and Gross, 2008).

In the current era of increased accountability and leader burnout, the district's role in supporting school leaders has expanded from one dedicated to "supervision to one focused on coaching, mentoring, and collaborating” (Thessin and Louis, 2019, p. 435). In charter and innovation schools, district personnel play an even larger role, becoming "vital institutional actors" in bringing the new school to life (Rorrer et al., 2008, p. 308). As one study found, school leader autonomy is "not freedom from interference; in fact, its effective use is predicated on support from the district" (Ford et al., 2020, p. 285). Even in charter and innovation schools, which have certain official freedoms (e.g., waivers from specific practices), autonomous schools are bound to district practices, which, in turn, honor state policies as part of the "vertical plane" implicit in the educational hierarchy (Lawson et al., 2017, p. 37).

In states like Colorado where the district is responsible for two discreet elements of school choice, leaders of charter and innovation schools remain connected to and must work 
closely with district leaders around accountability measures (Ryan, 2008), regardless of what an official waiver may declare. Moreover, there is no guarantee that the district's elected board the group approving applications - is aligned with the group responsible for overseeing the implementation of these new schools, the district's central staff employees. Consequently, conflicts can arise between the approved mission and vision of a charter or innovation school and the district's assessments of all schools.

As school choice becomes further entrenched in the education landscape, there is increased competition among schools for limited resources. Additionally, the already complex role of the school leader is magnified in charter and innovation schools and can lead to burnout if not addressed proactively by district leadership.

\section{Methods}

Using the Participatory Action Research (PAR) approach within the case study research method allowed for the collection of data on school leadership challenges in real time rather than espoused theory (Spillane et al., 2001). Furthermore, using a multisite, three year design added additional value by increasing "variation across the cases" (Merriam, 2009, p. 49) that resulted in a richer analysis.

For this study, three schools were selected through purposeful sampling (Creswell, 2007) using the following criteria: each was (1) a new charter or innovation high school, with (2) a focus on social justice and (3) a 2015 launch, within (4) a single metro-area school district in Colorado. Convenience sampling (Creswell, 2007) was used to identify leaders of schools that met these criteria. The first three leaders to be invited agreed to participate; no additional school leaders were approached given the rigorous interview schedule (i.e., monthly interviews for three years). 
The case study method is commonly critiqued for lack of "generalizability" (Creswell, 2007, p. 76), and this study is limited to three schools. However, case studies can produce transferable findings, so others may "apply the case to another situation" (Schoch, 2019, p. 246). The present study confronts the dearth of existing literature on leaders at standalone charter and innovation schools and uses a lens of "lessons learned" (Schoch, 2019, p. 246) from individual school leaders at these schools.

Study participants were school leaders at new charter or innovation high schools in an urban district in Colorado. All three schools were designed around social justice, intent on creating academic opportunities for students that differed meaningfully from a traditional large urban high school. The original three school leaders were part of their school's planning process, often known as Year 0 (zero). Of the founding leaders, only one participated in the entire threeyear study; the two other founding leaders left their schools before the study concluded. In these cases, subsequent school leaders were invited and agreed to participate in the study. For purposes of this paper, schools and school leaders have been given pseudonyms, and identifying characteristics have been removed.

Buffalo High School (BHS) was led by Tony Fisher for all three years of the study. BHS is a charter school dedicated to underserved youth, defined as students at risk of dropping out of school, often for issues related to gang activity, homelessness, and substance use/abuse. BHS is in the district's urban center. Due to its student population, the school is considered an Alternative Education Campus (AEC). The school model focused on individualized education and social justice. It opened with approximately 100 students and intended to grow to 130 at capacity, anticipating that few students would attend BHS for all four years and many would enroll mid-year. See Table 1 for a quantitative overview of BHS. 


\section{[Insert Table I about here.]}

Empowerment High School (EHS) was founded by Matt Jackson, who served in this role for Years 1 and 2; upon his resignation, founding assistant principal Mallory Garcia stepped in as principal. Located in the district's northeast quadrant, EHS is a STEM-based, college-track innovation school. As a form of social justice, the founders intended for all students to attain multiple college credits before graduation to mitigate the costs of higher education, a substantial barrier for students from underserved communities (U.S. Department of Education, 2021). In its first year, EHS served approximately 115 students, with the intent to grow by 100 students each year. By the end of Year 3, EHS enrolled approximately 250 students. See Table 2 for a quantitative overview of EHS.

[Insert Table II about here.]

Thomas Alva Edison High School (TAEHS) experienced many leadership changes after founding principal, Joey McGuire, resigned in the fall of Year 1. Abe Owens served as interim principal for the remainder of Year 1. Samantha Sherburne was appointed principal at the end of Year 1 and served for the remainder of the study. TAEHS was an innovation school designed to offer Advanced Placement (AP) courses to all students in the southwest section of the district. Historically, under-resourced students and students of color have been underrepresented and/or excluded from AP programs (Theokas and Saaris, 2013); thus, offering "AP to all" was designed as a form of social justice. In its first year, TAEHS served approximately 200 students, and added 200 freshmen each year of the study. See Table 3 for a quantitative overview of TAEHs.

\section{[Insert Table III about here.]}

The Colorado Department of Education requires that all districts monitor schools annually using a School Performance Rating (SPF), though districts may also create their own 
SPF within state-approved parameters. Each school's SPF ratings are illustrated in a color-coded system (Colorado Department of Education, 2021c); however, for simplicity, these colors have been translated into traditional letter grades for these tables, with an " $\mathrm{A}$ " meaning that the school is "meeting district expectations."

Honoring the model of participatory action research (PAR), as practiced in the Center for Practice Engaged Education Research (C-PEER) at the University of Colorado-Denver, this study was co-designed by me and the three founding school leaders with the intention of breaking down existing barriers, particularly unequal power dynamics, between researchers and practitioners (Call-Cummings and Hauber-Ozer, 2018). The Center believes it is essential to bring researchers and practitioners together to develop practical approaches to research that support improved practices in schools in a timely manner (C-PEER, 2015). To borrow a phrase from theater, I broke the fourth wall in this study. As stage actors do not traditionally interact with the audience, researchers traditionally do not interact with their subjects. Yet I was not a detached observer; I interacted directly with participants. Eager to establish collaborative conditions, the school leaders and I developed multiple contact points each year of the study. At the start of the school year, we co-wrote that year's semi-structured interview questions by sharing potential questions back and forth over email until everyone involved was satisfied with the content and phrasing of each question. At the end of each academic year, I prepared individualized narratives highlighting key findings for each school, based on those co-designed questions, and offered initial observations and comparisons from across the cohort. The school leaders and I discussed the findings and potential implications for practice and, in the second and third years of the study, used these conversations to generate new interview questions for the following year. These narratives also served as "member checking," an important step in locating 
researcher bias (Schoch, 2019) and ensuring accuracy. The school leaders reviewed multiple iterations of this article for the same purpose.

During the three years of the study, I met with school leaders monthly at their respective schools for one-on-one, 30-minute, semi-structured interviews. A majority of the data for this study came from these 76 interviews: seven at each school in Year 1, plus one with the founder of TAEHS after he resigned in fall of Year 1; and nine at each school in Years 2 and 3.

Interviews were recorded and manually transcribed by me or graduate research assistants. The questions changed annually, but centered on mission and vision implementation, internal and external challenges to the school model, and leadership wins and struggles. At points throughout the study, I also reviewed schools' approved charters or innovation plan and annual SPF ratings, noting how leaders' perceptions of their school mission and vision over time - or did not; how the schools performed within district parameters; and how leaders navigated various challenges.

The 76 monthly interviews were coded for themes and patterns, both within and across schools, in two distinct phases. First, upon completion of data collection, I coded the complete collection of interview transcripts using Dedoose software. I used in vivo coding, allowing the data to produce the themes rather than imposing themes upon the data (Merriam, 2009; Schoch, 2019). From this first stage of analysis, six themes and nine subthemes emerged. Following this, I used analytical coding to rethink the themes into broader categories, allowing new meanings to emerge, as I reread and reflected upon the data collected over three years. Second, I did a final manual coding of the interviews. Through this, two key themes emerged: one, school-leader burnout is a formidable threat, as the work of leading a new school was more demanding and complex than leaders anticipated; and two, district policies and practices combined to create 
direct and indirect barriers that negatively impacted each school leader's ability to bring the school's mission and vision to life.

\section{Results}

The data collected in this study highlight both the strong potential for leadership burnout and the district barriers school leaders faced as they tried to actualize their schools' approved charter and innovation plans. The first theme, Leadership Burnout, comprises two sub-themes that directly contributed to participant burnout: overwhelming operational demands and work-life imbalance. The second theme, District Barriers to Implementation, identifies elements external to the school that inhibited school leaders from implementing the mission and vision with fidelity, and included four sub-themes: one-size-fits all accountability, district inflexibility, lagging funding, and the Hunger Games conundrum.

\section{Theme 1: Leadership Burnout}

As they wrestled with operational demands, long hours, and the general intensity of leading a school, the school leaders experienced burnout. Additionally, feelings of isolation and a lack of preparedness contributed to an overall sense of exhaustion.

Overwhelming operational demands. The work of leading a new autonomous high school was markedly different from what leaders anticipated. Contrary to their expectations, operational demands trumped instructional leadership. For Fisher, the founder of BHS, leading a new school was "a lot more like running a business." Before leading BHS, Fisher was a master teacher. He joined the founding group of BHS because he anticipated that leading school instruction aligned with his vision of social justice. Yet, much of his work "had nothing to do with actual teaching and learning." He reflected that he had focused his planning year on 
curriculum; in reality, he should have "prepare[d] with a lot more of the operational and technical knowledge" that it takes to run a school. He confided that it took longer than necessary to complete certain operational basics because he tried to learn everything himself, rather than use his limited financial resources to hire experts:

I waited a really long time because I was trying to figure everything out on my own...It took a year and a half, literally, to get our phone lines working because we were dealing with so many different funding sources.

Overseeing the construction of an actual school building or a school's relocation were also unexpected elements of the job for the school leaders. As the TAEHS campus continued to expand during its first three years, Sherburne regularly attended architectural meetings, yet felt out of her element in doing so:

I'm a principal...I'm not an architect. I mean, I can tell [the district] what I need, but I don't have the time to sit and figure out where the main office should actually be...I'd rather have people who are experts in school buildings walk it with me, let me talk about how we use certain things, and then help figure this out. I'm certainly not an expert, and that's uncomfortable for me to have to lead.

In the fall of Year 3, BHS encountered problems with the organization that owned the school building. Fisher found himself learning commercial real estate logistics in real time. His days were spent visiting empty buildings, navigating real estate contracts, and learning city zoning laws. Fisher successfully found a new home for BHS, but the red tape around zoning made the process particularly cumbersome.

Over at EHS, Garcia wrestled with construction projects. As she stepped into her new role as principal at the end of Year 2 (following Jackson's departure), she inherited oversight of 
the school's move from one district building to another. As construction fell behind, Garcia found herself overseeing district renovation policies and timelines, while also trying to establish herself as the school leader and create a positive school culture in a new building that was barely ready for students or faculty.

Work-life imbalance. Leading a new school was a personally intense and demanding experience. Leaders felt there was no end to the work. In February of Year 1, Fisher was conflicted about returning to BHS for Year 2 because the work was so different from what he had expected:

Probably naïvely, I would have said, 'Yeah, 60-70\% of my time will be focused on instruction.' That number is probably closer to $10 \%$...I don't know moving forward what's going to happen, in all honesty...I think a lot about going back to being a math teacher again.

Jackson was similarly uncertain about his future at EHS due to the time-consuming nature of leading the school. He shared that during Year 1, he and his wife discussed his work schedule and concluded that he would have to "find a way to make this job more balanced, because it's not." When he could not find a way to create the needed balance between running a school and being a husband and father, he left the job. At the start of Garcia's tenure at EHS, she was working full days at school, going home and working another three plus hours, and working every weekend. Just a few months into her role, she shared, "if the whole year feels like it did this first month," then "[I'm] not long” for the job.

In addition to the workload, leading a new school was a lonely experience. Fisher felt "pretty isolated" within BHS. As a teacher, Fisher had colleagues with whom he could talk when wrestling with tough ideas or challenging situations; as a school leader, though, this was not the 
case. He missed the companionship and collaboration of previous roles. Garcia reflected that, even as a co-founder and assistant principal of EHS, her understanding of the true nature of the work shifted only when she became principal. She admitted that she had quietly questioned some of Jackson's decisions in Years 1 and 2. It was only when she became principal that she realized "how hard it was." But, she asserted, "you just don't know what you don't know."

The intensity of the job, combined with workday realities so different from what they anticipated, caused most leaders to openly question if they could or would stay in the position. Fisher questioned, if "the reality is different than what I signed up for...is this really what I want to do?" For Jackson, the answer was ultimately no. In May of Year 2, he resigned and took a district-level job in a different part of the state. He clarified that this new role was not a "moveup-the-ladder" change, but a "take-care-of-the-family" change. He was nervous about how his departure might impact the school he had created and loved, but these reservations were not enough to stop him from doing what he thought was best for him and his family, which meant leaving the school he founded after only two years.

\section{Theme 2: District Barriers to Implementation}

In addition to navigating individual challenges during their schools' first three years, the leaders regularly collided with district barriers as they tried to implement the mission and vision with fidelity. The school board approved the charter and innovation plans; yet, the district itself had internal systems that made realizing the original missions and visions difficult. Leaders at each school ran into structural barriers at the district level around accountability measures, enrollment, finances, or a combination therein.

One-size-fits-all accountability. District accountability measures, as determined by SPF, created myriad challenges for the new schools as district priorities differed from school 
priorities. Fisher believed that the district's SPF measures negatively impacted his ability to implement BHS's mission with fidelity, as he thought neither the academic nor attendance metrics in the SPF provided "an accurate representation" of BHS. Consequently, in Year 1, he encouraged his teachers not to modify their instruction to try to succeed on SPF metrics: In all honesty, we intentionally did not spend our time trying to make sure that the accountability measures would be good...We just didn't [do it] because we felt like delivering the curriculum and instruction that we believe is good for students trumps test preparations.

After BHS received very low SPF marks for Year 1, however, Fisher realized that low SPF results could threaten BHS's existence over time; consistently low SPF scores could cause the district to deny BHS's reapproval in a few years. Thus, although he believed that the SPF did not produce meaningful measures of BHS students' progress and that classroom SPF test preparations could negatively impact student learning, he revised school policies to increase SPF ratings and advised teachers to spend more time preparing for state testing. Fisher yielded to the demands of the SPF assessments to keep his school open.

Making these changes distressed Fisher because he believed it put the district's assessment ahead of the school's mission. For instance, to achieve higher results on one element of the SPF, Fisher modified the school's attendance policy. In Year 1, if students had an extended absence, they would remain enrolled and be welcomed whenever they returned. However, in Years 2 and 3, a student who met the pre-determined absence length would be automatically unenrolled and required to reenroll when they next came to school. Fisher was upset with this policy change because it did not honor his students' realities: 
When you really dig down and find out why [students] are not coming to school and some of the barriers that they have, you realize our students have a ton of grit and resilience that you don't see on the surface. Dealing with everything from domestic violence to abusive parents to parents who have addictions to being homeless to all those things.

With such complicated reasons for missing school, Fisher feared the new policy would discourage reenrollment. Fisher also disliked that changing the enrollment policy made him feel like he was "gaming" the system and undermining BHS's mission. After changing the enrollment policy, Fisher questioned: "How do we stay true to the model and then also meet accountability measures that don't necessarily support the model?"

District inflexibility. The district's enrollment policies, and the funding tied to them, created enormous barriers for EHS. For Jackson, the mission and vision were his "north star." Jackson explained that, for himself and his team, "this is the key: we try to anchor everything back to the school vision." In Year 1, this worked well: Jackson oversaw the implementation of new pedagogy; students were thriving in the new model; and his district supervisors told him that "something really special" was going on at EHS. The social justice element of the model was being actualized and the school received high SPF ratings. However, because EHS was the only non-charter high school in the district without a feeder middle school, enrollment for Year 2 was lower than expected. With school funding tied directly to student enrollment, the gap between expected and actual enrollment resulted in a significant budget shortfall in Year 2. Jackson appealed to the district for financial support, citing the school's stellar SPF ratings, but he was rejected. 
In the short term, EHS was financially stable because Jackson had been fiscally conservative in Year 1 and had slightly more in savings than the shortfall. However, the money had been earmarked to provide students with social-emotional supports connected to the school's mission. With the unexpected enrollment gap, Jackson was forced to reallocate these funds to cover the transportation budget. He saved the budget, but at the expense of the very programming that differentiated EHS from other high schools.

In these critical early years, the enrollment shortfall and accompanying budget concerns proved highly detrimental to EHS. After Jackson resolved the second year's financial crisis, he reached out to district supervisors to explore the enrollment-pattern challenge (i.e., no feeder middle school). Jackson implored district leaders to provide further enrollment support; again, he was denied. Modifying the existing practices, district leaders informed him, would create a "ripple effect" across the system. Every school, they explained, must compete for enrollment. If the district connected EHS to a specific middle school, it would decrease enrollment at another high school. As Jackson saw it, EHS was "bearing the brunt" of the district's flat enrollment overall. He was persistent but resigned: 'I'll continue to do everything I can, and be creative, and do the fundamentals of recruitment well, but some of this may be beyond our control." Ultimately, Jackson noted, the biggest threat to the school's long-term success [is] not having the consistent input of an enrollment pattern...We're going to be fiscally challenged for the long-term sustainability major league if we can't have better enrollment patterns. [I am] almost feeling like we're set up to fail.

The enrollment challenges persisted as Garcia took over the leadership at EHS, despite a new location in Year 3. At the close of the study, Garcia anticipated the problem continuing as she 
prepared for Year 4. The school's SPF scores went down in Years 2 and 3 as the school continued to lack funding for specific programming measures that would have brought the original mission and vision to life.

Lagging funds. Like EHS, financial woes were particularly devastating to the actualization of the mission and vision of TAEHS. The original TAEHS budget underestimated the costs of an AP-for-all approach. "AP for all" was about social justice: all students who wanted a rigorous academic experience could attain one by enrolling in this non-magnet, nontesting program. As interim principal Owens understood it, TAEHS was designed to be a school that would "level out the playing field, socioeconomically and ethnically." Yet, students entered the school with significantly different academic preparation. Within the first few months, offering only one level of each course appeared flawed. Owens questioned: "[W]here are all the supports for kids who are coming in from vastly different demographics, with vastly different reading levels, with vastly different mathematics skills?” By December of Year 1, the internal academic data showed 55\% of students were failing language arts and $66 \%$ were failing math. Owens asked the district for additional resources to support student learning, such as pre- $9^{\text {th }}$ grade summer testing and school prep, but he was denied.

Owens tried to rearrange schedules and find funding for additional push-in classroom support. When Sherburne took over from Owens, she similarly sought ways to hold onto the original vision while simultaneously supporting all students to learn at this high level. At the start of Sherburne's tenure in fall of Year 2, she articulated "AP for all" as an inclusive model, where teachers would "differentiate and scaffold" in each classroom. She further explained that the TAEHS model was driven by the vision "that all students can learn at high levels in an inclusive classroom. That's at the heart of everything we do. This will never be a track school.” 
But as students continued to struggle and she received no additional financial support from the district, her commitment to the original mission waivered in favor of an array of levels for most courses to ensure "we're meeting the needs of all kids." In Year 3, Sherburne further revised her perspective on "AP for all," explaining that the administrative team now defined "AP for all" as AP-course "exposure and opportunity for all," which meant some students would take a full AP course load and exams, while others would take only two AP courses (literature and world history) with no exam requirement. In reflecting on this change, she stated, "for a lot of our kids, the benefit is just being exposed to that type of rigor; it's not about taking the test." The "AP for all" model was far more expensive in practice than in the school's original budget and budget forecasts. Owens and Sherburne asked the district for additional funds to reduce class size, provide extra tutoring, and cover the actual cost of testing for all students who wanted to sit for AP tests. Like Jackson at EHS, Sherburne saw a clear link between programming, enrollment, and funding: if the funding was not there to support the programming, then she feared students would stop enrolling; if students stopped enrolling, then there would be a domino effect of losing even more funding. Yet Sherburne believed this pattern was timelimited, and TAEHS only needed early financial support. "Within three years [of being fully operational]," Sherburne noted, "we can fund ourselves. We will have everything that we need [then], but we need to have the influx right now to help us get there." Yet to build out a program that would be sustainable, TAEHS first needed additional financial support from the district. Sherburne eventually convinced the district to provide "very generous" funds to support testing. This was helpful, but "still not enough" to cover all the costs. The school never reverted to the original definition of "AP for all." 
The Hunger Games conundrum. In addition to the various district barriers the leaders experienced as they sought to bring their schools to life, they were befuddled by the district board's approval of additional charter and innovation schools. From Sherburne's perspective at TAEHS, she declared: "We're in an arms race. How many schools can [the district] open? And how many schools are we going to damage in the process?" Over at EHS, Garcia was similarly perplexed by the board's approval of new high schools, particularly those with similar pedagogy to EHS. Reflecting on this and on the district's continued refusal to help with their enrollment gap, Garcia asserted, "I don't get it, as far as the district wanting us to survive." She called it the "Hunger Games effect," comparing the competition among new schools for resources with the Young Adult book series where individuals compete to the death. Interim-TAEHS principal Owens' summed up the district's continuing approval of new schools without providing adequate support to the existing young new schools as "educational malpractice."

\section{Discussion}

The purpose of this multisite case study was to understand how school leaders navigated the journey from a school-in-theory to a school-in-practice over the first three years of operation. The research identified two key findings with myriad ramifications for school leadership practice: first, the strenuous and multi-faceted work of opening a school in isolation led to burnout; second, district barriers stymied authentic implementation of schools' missions and visions. To reduce leadership attrition, prevent needless school closures, and avoid the subsequent academic losses among students, a collaborative approach from graduate schools, foundations, and districts is needed to address these challenges.

\section{Mitigate Leadership Burnout}


Despite extensive literature on the ever-increasing demands on school leaders (Leithwood et al., 2004; Allen and Gawlik, 2009; Finn et al., 2017; Gawlik, 2019; Yan, 2020), the actual work of leading a new charter or innovation school was even more difficult than anticipated for the individuals in this study. Moreover, given disturbing trends in principal turnover in recent years (School Leaders Network, 2014; Yan, 2020), it is imperative to understand the causes of leadership burnout to develop policies and practices that might address it. For school leaders in this study, their previous experiences in graduate school and as educators did not adequately prepare them for the job. Given the national proliferation of charter schools, educational leadership programs must "prepare students for leadership in both district and charter schools" (Allen and Gawlik, 2009, p. 21). Additionally, university leadership programs typically differentiate between building leaders and district leaders (Allen and Gawlik, 2009), but leaders at autonomous schools often act as both. As the only charter school leader in this study, Fisher would have benefitted most from principal preparation coursework that offered guidance about the operational elements of charter schools.

The school leaders in this study would also have benefited from networking opportunities with peers in like roles or from mentorships. The literature indicates that informal social networks have a positive impact on educators (Gawlik, 2019) and facilitate the creation of “enduring interpersonal relationships" (Liou and Daly, 2018). Similarly, participating in a mentorship, and thereby building a trusted relationship, can positively impact novice leaders' by improving their skills in areas of communication, time management, and problem solving and reducing feelings of isolation (Connery and Frick, 2021). The extensive operational demands of running a standalone new school requires individuals to wear many hats: operations manager, instructional leader, HR department head, snow-day decision maker, lunch person, hall monitor, 
and more. Connecting with others experiencing similar demands or who have already navigated such work diminishes the sense of isolation while providing meaningful opportunities to learn from peers.

\section{Mollify District Barriers}

This study indicates that districts do indeed play an active role in the success or failure of new charter and innovation schools. Realizing a school's mission and vision requires a delicate balance between an individual leader's understanding of the work and the authorizing district's practices around accountability, enrollment, and school finance (Ford et al., 2020). Moreover, as Jackson learned in real time, the board's approval of a charter or innovation plan should not be interpreted as the district committing to the school's success.

Accountability measures, as defined by the SPF, were not aligned between the district and BHS. In fact, Fisher felt he was actively harming students when he prioritized the SPF; but, because of state law around charter approval, he felt he had no choice. At EHS, the district's enrollment policies created impenetrable barriers that resulted in fewer students than expected, which fundamentally damaged the school budget and, in turn, their programming. As foundations have moved away from supporting standalone charter schools toward supporting charter replication models (Kingsbury, et al., 2020), these financial demands will fall to the district, though the shortfalls will be felt acutely by individual schools. The original, districtapproved TAEHS budget underfunded pieces of the school's original mission and vision. This lack of funds fundamentally altered the type of programming offered and Sherburne's ability to implement the original mission and vision with fidelity. "AP for all," with its social justice focus, quickly became AP-exposure for all, with only the elite students prepared for and completing the formal tests. 


\section{Implications for Future Research}

To determine the transferability of the results of this study, one potential quantitative study could explore the lived experiences of school leaders at new charter and innovation schools in multiple districts in and beyond Colorado. Like many charter school leaders, the school founders in this study were novice school leaders (Leukens, 2004). Thus, another study might further explore the connection between novice school leadership, leadership burnout, and autonomous schools. Additionally, further research into the relationships between standalone autonomous schools and district systems would increase understanding of how district practices impact innovation and implementation at the school level.

Finally, as researchers and policymakers continue to explore which methodologies best examine the intersection of policy and practice, "innovation and experimentation" are lauded (Lochmiller, 2018, p. 6). There were three primary benefits to this collaboration between researcher and practitioners, to breaking the fourth wall. First, it produced data that was meaningful to the participating school leaders, rather than for academic purposes alone. Second, the school leaders appreciated the real time information. Third, the predictable monthly interview created regular opportunities for school leaders to reflect, which helped them "identify challenges, devise actions, and consider impacts" (Lochmiller, 2014, p. 79). Although there are reasons to be cautious when creating or synthesizing methodologies, these potential drawbacks should inform best practices and not undermine the practice altogether.

\section{Conclusion}


The literature indicates that strong school leaders create successful, high performing schools when they have an "above average" vision for their school (Chubb and Moe, 1990, p. 85). Yet, these findings illustrate that autonomy around curriculum, budget, scheduling, and personnel without autonomy over school-success measures, is misleading. As leaders at charter and innovation schools are required to delineate how and why they want to educate, they must also be able to help determine appropriate measures of success. Chubb and Moe (1990) warned three decades ago that schools do not stymie progress in education reform; rather, school districts do, as they "inherently breed bureaucracy and undermine autonomy" (p. 188). If leaders at standalone charter and innovation schools fail to enact their mission and vision with fidelity, the blame rests with the school leader; yet the policies and practices within the authorizing district must be examined as well. Empowering a school to enact its mission and vision, while also requiring it to honor district practices that directly or indirectly prevent successful implementation of the same mission and vision, sets schools up to fail.

The lived reality of school leaders during a charter or innovation school's inaugural three years reveals the unintended costs of launching a new high school, both for leaders and schools. To increase the success of future school leaders and new schools, it is imperative that leadersand those connected to their work-attain a better understanding of the challenges inherent to starting and running such new charter and innovation high schools, as well as how implementation of the founding mission and vision are impacted by the authorizing district's structures and systems.

\section{Acknowledgements}


This research was supported by Kent Seidel and the Center for Practice Engaged Education

Research at the University of Colorado-Denver.

\section{Declaration of conflicting interest}

There are no known conflicts of interest.

\section{Funding}

The author received financial support for this research from the Donnell-Kay Foundation and the Rose Community Foundation, but received no financial support for the authorship and/or publication of this article.

\section{References}

Allen, A. and Gawlik, M. (2009), "Preparing District and Charter School Leaders: A Systems Perspective", National Council of Professors of Educational Administration, Vol. 10 No. 2, pp. 27-36.

Altrichter, H. (2010), "Theory and Evidence on Governance: Conceptual and Empirical Strategies of Research on Governance in Education", European Educational Research Journal EERJ, Vol. 9 No. 2, pp. 147-158.

Bauer, S. and Silver, L. (2018), "The impact of job isolation on new principals' sense of efficacy, job satisfaction, burnout and persistence", Journal of Educational Administration, Vol. 56 No. 3, pp. 315-331.

Bierly, C. and Shy, E. (2013), Building Pathways: How to Develop the next Generation of Transformational School Leaders, Bain, Boston.

Bulkley, K. and Fisler, J. (2003), "A Decade of Charter Schools: From Theory to Practice”, Vol. 17 No. 3, pp. 317-342.

Cahill, R. and Gray, J. (2010), "Funding and secondary school choice in Australia: a historical consideration", The Australian Journal of Teacher Education, Vol. 35 No. 1, pp. 121138. 
Call-Cummings, M. and Hauber-Ozer, M. (2018), "The Potential of (Participatory) Action Research for School Leaders, Local Policy Makers, and University-Based Researchers", Complementary research methods for educational leadership and policy studies, edited by Lochmiller, C., Palgrave Macmillan, Cham, Switzerland, pp. 121-140.

Campbell, C. and Gross, B. (2008), "Working Without a Safety Net: How Charter School Leaders Can Best Survive on the High Wire," National Charter School Research Project, Seattle, Washington.

C-PEER, Center for Practice Engaged Educational Research. (2015), available at: https://education.ucdenver.edu/research-and-centers/centers-initiatives/c-peer.

Chetty, R., Friedman, J.N. and Rockoff, J.E. (2011), “The Long-Term Impacts of Teachers: Teacher Value-Added and Student Outcomes in Adulthood", Vol. 17699, National Bureau of Economic Research, Cambridge, MA.

Chubb, J.E. and Moe, T.M. (1990), Politics, Markets, and America's Schools, The Brookings Institute, Washington, D. C.

Cleaver, S. (2010), “The Principal Pipeline”, available at: https://www.gse.harvard.edu/news/ed/10/05/principal-pipeline.

Colorado Department of Education (2021a), "Application Checklists", available at: https://www.cde.state.co.us/cdeprof/licensure authorization landing.

Colorado Department of Education (2021b), "Colorado Charter Schools Introduction," available at: https://www.cde.state.co.us/cdechart/chintro.

Colorado Department of Education (2020), "List of all charter schools (2019-2020)", available at: https://www.cde.state.co.us/cdechart.

Colorado Department of Education (2021c), "SchoolView", available at: http://www.cde.state.co.us/schoolview/performance.

Colorado Educator Licensing Act of 1991, Code of Colorado Regulations. Available at: https://www.sos.state.co.us/CCR/GenerateRulePdf.do?ruleVersionId=7160.

Colorado Revised Statutes (2016), available at: https://law.justia.com/codes/colorado/2016/title22/school-districts/article-30.5/part-1/section-22-30.5-108/.

Connery, L.A. and Frick, W.C. (2021). "A Formal Administrator Mentoring Program: Perceived Learning Benefits and Insights into Leadership Well-being." i.e.: inquiry in education, Vol 13 No 1.

Creswell, J. (2007), Qualitative Inquiry and Research Design: Choosing Among Five Approaches, Sage Publishers, Inc., Thousand Oaks, CA.

Dong, H. and Li, L. (2019), "School Choice in China: Past, Present, and Future", ECNU Review of Education, Vol. 2 No. 1, pp. 95-103.

Elmore, R.F. (2000), Building a New Structure for School Leadership, The Albert Shanker Institute, Washington, DC.

Finkelstein, N.D. and Grubb, W.N. (2000), "Making Sense of Education and Training Markets: Lessons from England," American Educational Research Association, Vol. 37 No. 3, pp. 601-631. 
Finn, C.E., Manno, B.V. and Wright, B.L. (2017), "Improve governance for charters", Kappan, Vol. 98 No. 6, pp. 63-69.

Ford, T.G., Lavigne, A.L., Fiegener, A.M. and Si, S. (2020), "Understanding District Support for Leader Development and Success in the Accountability Era: A Review of the Literature Using Social-Cognitive Theories of Motivation", Review of Educational Research, Vol. 90 No. 2, pp. 264-307.

Gawlik, M.A. (2019), "Principal Socialization in Charter Schools", Journal of School Leadership, Vol. 29 No. 1, pp. 3-24.

Honig, M. (2012), "District Central Office Leadership as Teaching: How Central Office Administrators Support Principals' Development as Instructional Leaders”, Educational Administration Quarterly, Vol. 48 No. 4, pp. 733-774.

Honig, M. and Rainey, L. (2014), "Central Office Leadership in Principal Professional Learning Communities: The Practice Beneath the Policy", Teachers College Record, Vol. 116, pp.1-48.

Innovation Schools Act of 2008 (2008), available at: https://www.cde.state.co.us/choice/innovationschoolsstatute.

Jabbar, H. (2015). “'Every kid is money': Market-like competition and school leader strategies in New Orleans", Educational Evaluation and Policy Analysis, Vol. 37 No. 4, pp. 638-659.

Jabbar, H. (2016). "Between structure and agency: contextualizing school leaders' strategic responses to market pressures", American Journal of Education, Vol. 122 No. 3., pp. 399-431.

Kingsbury, I., Maranto, R. and Karns, N. (2020), “Charter School Regulation as a Disproportionate Barrier to Entry", Urban Education, pp. 1-27.

Kottenstette, B. and Paga, P. (2020), “2020 Innovation Schools Annual Report”, Colorado Department of Education, School Quality and Support Division/Schools of Choice Unit.

Lawson, H.A., Durand, F.T., Wilcom, K.C., Gregory, K.M., Schiller, K.S. and Zuckerman, S.J. (2017), "The Role of District and School Leaders' Trust and Communications in the Simultaneous Implementation of Innovation Policies", Journal of School Leadership, Vol. 27, pp. 31-67.

Leithwood, K., Louis, K.S., Anderson, S. and Wahlstrom, K. (2004), "Review of research: How Leadership Influences Student Learning”, Wallace Foundation, New York, NY.

Levin, S. and Bradley, K. (2019), "Understanding and Addressing Principal Turnover: A Review of the Research," National Association of Secondary Schools, Reston, VA.

Levine, A. (2005), "Educating School Leaders", The Education Schools Project, New York City. Liou, Y.-H. and Daly, A.J. (2018), "Broken bridges: a social network perspective on urban high school leadership", Journal of Educational Administration, Vol. 56 No. 5, pp. 562-584.

Lochmiller, C. (2014), "Leadership Coaching in an Induction Program for Novice Principals: A 3-Year Study", Journal of Research on Leadership Education, Vol. 9 No. 1, pp. 59-84.

Lochmiller, C. (2018), Complementary Research Methods for Educational Leadership and Policy Studies, Palgrave Macmillan, Cham, Switzerland. 
Luekens, M.T. (2004), "Who's the Boss?: An Examination of the Characteristics, Experience, and Training of Charter School Principals", presented at the Annual Meeting of American Educational Research Association (AERA).

Merriam, S.B. (2009), Qualitative Research: A Guide to Design and Implementation, JosseyBass, San Francisco, CA.

Miron, G., Gulosino, C., Shank, C., Elgeberi, N., Davidson, C., Hernandez De Alvarez, F., Jurdzy, B., Larsen, J., Pham, D., Ruder, K., Urdapilleta, L., \& Urschel, J. (2021). "Profiles of For-Profit and Nonprofit Education Management Organizations: Fifteenth Edition.” Boulder, CO: National Education Policy Center.

National Center for Education Statistics (2021), "Public Charter School Enrollment," available at: https://nces.ed.gov/programs/coe/indicator/cgb (accessed 1 June 2021).

Ni, Y., Sun, M. and Rorrer, A. (2015), "Principal turnover: Upheaval and uncertainty in charter schools?", Educational Administration Quarterly, Vol. 51 No. 3, pp. 409-437.

Potterton, A. U. (2019). “Leaders' experiences in Arizona's mature education market”, Journal of Educational Administration, Vol. 57 No. 1, pp. 21-35.

Rorrer, A.K., Skrla, L. and Scheurich, J.J. (2008), “Districts as Institutional Actors in Educational Reform”, Educational Administration Quarterly, Vol. 44 No. 3, pp. 307 358.

Rothstein, R. (2001), “Charter Conundrum”, available at: https://prospect.org/education/charterconundrum.

Ryan, J. (2008), "Charter Schools and Public Education”, Stanford Journal of Civil Rights and Civil Liberties, Vol IV No. 2, pp. 393-410.

Schoch, K. (2019), Case Study Research, edited by Burkholder, G., Cox, K., Crawford, L. and Hitchcock, J., SAGE Publications, Inc., Los Angeles, CA, pp. 245-258.

School Leaders Network. (2014), Churn: High Cost of Principal Turnover.

Spillane, J.P., Halverson, R. and Diamond, J.B. (2001), "Investigating School Leadership Practice: A Distributed Perspective", Educational Researcher, pp. 23-27.

Theokas, C. and Saaris, R. (2013), Finding America's Missing AP and IB Students, The Education Trust.

Thessin, R.A. and Louis, K.S. (2019), "Supervising school leaders in a rapidly changing world", Journal of Educational Administration, Vol 57 No 5, pp. 434-444.

U. S. Department of Education. (2021) "College Affordability and Completion: Ensuring a Pathway to Opportunity," available at: https:/www.ed.gov/college.

Waters, T., Marzano, R. and McNulty, B. (2003), Balanced Leadership: What 30 Years of Research Tells Us about the Effect of Leadership on Student Achievement, McRel.

Windler, W. (1996), “Colorado's Charter Schools: A Spark for Change and a Catalyst for Reform," The Phi Delta Kappan, Vol. 78 No. 1, pp. 66-69.

Yan, R. (2020), "The Influence of Working Conditions on Principal Turnover in K-12 Public Schools," Educational Administration Quarterly, Vol. 56 No. 1, pp. 89-122. 
Zellner, L., Ward, S., McNamara, P., Gideon, G., Camacho, S. and Doughty, S. (2002), The loneliest job in town: Sculpting the recruitment and retention of the principal. Paper presented at the Annual Meeting of the Southwest Educational Research Association, Austin, TX. 